\title{
DNA amplification from pin-mounted bumble bees (Bombus) in a museum collection: effects of fragment size and specimen age on successful PCR*
}

\author{
James P. STRANGE, Joyce KNOBLETT, Terry GRISWOLD \\ USDA-ARS, Bee Biology and Systematics Laboratory, Utah State University, BNR 255 Logan UT 84322-5310, \\ USA
}

Received 28 December 2007 - Revised 28 August 2008 - Accepted 15 November 2008

\begin{abstract}
Historic data in the form of pinned specimens in entomological collections offer the potential to determine trends in genetic diversity of bumble bees (Bombus). We screened eight microsatellite loci in pinned bumble bee specimens from the U. S. National Pollinating Insects Collection. We tested three species (Bombus appositus, Bombus huntii and Bombus occidentalis) representing three subgenera of bumble bees (Subterraneobombus, Pyrobombus and Bombus sensu stricto) respectively. Bombus occidentalis is a species of particular concern for conservation biologists. Single mid-legs of ninety-six individuals from each species were assayed to determine microsatellite amplification success rates of historic material in a museum collection. Microsatellite alleles amplified in specimens up to 101 years old, but the rate of amplification success was significantly lower in material over 60 years of age. Loci with shorter allele sizes amplified more frequently than relatively longer alleles in samples from all age classes. We correlate the age of specimens to the age at which loci fail to amplify and discuss potential impacts of using certain markers for population genetic studies of museum specimens.
\end{abstract}

Bombus / museum specimens / conservation genetics / microsatellite / ancient DNA / PCR success rate

\section{INTRODUCTION}

There is concern that some North American bumble bees (Bombus) are in decline and may be headed for extinction (Colla and Packer, 2008). Local extinction has been documented for B. occidentalis Greene (McFrederick and Lebuhn, 2006) and B. affinis Cresson (Colla and Packer, 2008), and B. franklini Frison may be extinct (Thorp and Shepherd, 2005). How can we detect such declines? One possibility is to directly census bumble bees; however, bumble bee populations are highly variable interannually, and given the social nature of the genus, large numbers of individuals at a location can potentially represent few colonies.

Corresponding author: J.P. Strange, james.strange@ars.usda.gov

* Manuscript editor: Walter S. Sheppard
Significant declines may not be detected in time for possible interventions or interannual variation may be misinterpreted as long term decline. As an alternative to field abundance surveys, one could use museum collections to compare recent with historic levels of genetic diversity. Molecular methods provide useful conservation and ecological tools to assess bumble bee population size, colony density, and genetic diversity (Ellis et al., 2006; Knight et al., 2005; Darvill et al., 2004). Are techniques used to determine genetic diversity in bumble bee populations also suitable to measure historic levels of genetic diversity in museum-preserved specimens?

Entomological museum collections are rich repositories of insect fauna and provide historical data on species distribution and diversity. Collections frequently house substantial 
numbers of specimens from intensively sampled locations, making them appealing sources for longitudinal population genetic studies and species conservation (Groombridge et al., 2000; Rosenbaum et al., 2000; Goldstein and DeSalle, 2003; Austin and Melville, 2006; Martínková and Searle, 2006; Harper et al., 2008; Konopinski, 2008). Ancient DNA has been recovered from a broad range of species preserved in various ways (Rosenbaum et al., 2000, 1997; Goldstein and DeSalle, 2003; Austin and Melville, 2006; Martínková and Searle, 2006). Watts et al. (2007) demonstrated that nuclear DNA could be used to generate multilocus microsatellite genotypes from fifty year old damselfly tarsi taken from museum specimens. Here we test the feasibility of obtaining multilocus microsatellite genotypes from pin-mounted bumble bee species, one thought to be declining or having undergone a recent population bottleneck, which could be used ultimately to detect historic levels of population genetic diversity for comparison with recent or current diversity (Groombridge et al., 2000; Rosenbaum et al., 2000; Harper et al., 2008).

We assessed the feasibility of using DNA extracted from legs of pin-mounted bumble bee specimens as template DNA for amplification of eight microsatellite loci (Estoup et al., 1996; Funk et al., 2006) in three species of bumble bees, Bombus appositus Cresson, Bombus huntii Greene and B. occidentalis. These three species represent three subgenera Subterraneobombus, Pyrobombus and Bombus sensu stricto. The loci selected encompass a diversity of allele fragment sizes and amplify across a broad range of Bombus species (Funk et al., 2006; Strange, unpubl. data).

\section{MATERIALS AND METHODS}

Historic samples of pin-mounted bumble bees were obtained from the U. S. National Pollinating Insects Collection at the USDA-ARS Bee Biology and Systematics Laboratory in Logan, UT. Approximately 12000 specimens of Bombus are in the collection, representing material collected from 1893 to the present. This Bombus collection is noteworthy because it contains substantial numbers of $B . o c$ cidentalis $(4.3 \%$ of the bumble bee specimens in the
Pollinating Insect Collection) collected from locations distributed widely throughout the western US. Ninety-six individuals (male and female) of each species were selected from the collection to represent historic samples. We selected material at approximately decadal intervals from a broad range of collectors and various collection techniques (net collected, baited traps, pan traps, malaise traps, etc.) to reduce potential differential effects of collection technique or post collection handling. As material was less abundant in earlier decades, some decades (especially the 1930s) were not well represented in the data set. Specimens were grouped by age such that samples 0-9 yr, 10-19 yr, 20-29 yr, .., 100$109 \mathrm{yr}$ comprised 11 age classes. The mean age of specimens was $50.4 \mathrm{yr}, 50.1 \mathrm{yr}$ and $45.1 \mathrm{yr}$ for $B$. huntii, B. occidentalis and B. appositus, respectively.

Specimens were sampled by removing a midleg from each specimen and placing the leg in a $0.2 \mathrm{~mL}$ well of a 96 well PCR plate containing $150 \mu \mathrm{L}$ of a $5 \%$ Chelex $^{\circledR}$ extraction solution (modified from Walsh et al., 1991). The leg was submerged, and then crushed with forceps to break the exoskeleton and expose the dried muscle tissue to the solution. Proteinase $\mathrm{K}(5 \mu \mathrm{L}$ of $10 \mathrm{mg} / \mathrm{mL})$ was added to each well and samples were incubated for $1 \mathrm{~h}$ at $55^{\circ} \mathrm{C}, 15 \mathrm{~min}$ at $99{ }^{\circ} \mathrm{C}, 1 \mathrm{~min}$ at $37{ }^{\circ} \mathrm{C}$ and 15 min at $99{ }^{\circ} \mathrm{C}$. Extracted DNA was stored at $4{ }^{\circ} \mathrm{C}$ until PCR amplifications. Eight polymorphic microsatellite loci (Estoup et al., 1996; Funk et al., 2006) were used for analysis of each species (Tab. I). Of the loci surveyed, seven amplified in $B$. appositus and B. occidentalis while all eight loci amplified in B. huntii. DNA was PCR-amplified in two $10 \mu \mathrm{L}$ multiplex reactions containing $1 \mu \mathrm{L}$ extracted DNA, 1x Promega (Madison, WI) reaction buffer, $0.6 \mathrm{mM}$ dNTP mixture, $0.2-0.4 \mu \mathrm{M}$ primer, $0.001 \mathrm{mg}$ BSA, 0.4 units Taq polymerase (Promega, Madison, WI) and the $\mathrm{MgCl}_{2}$ concentration was adjusted to $1.4 \mathrm{mM}$. The PCR conditions for both multiplex reactions were one $7 \mathrm{~min}$ cycle at $95{ }^{\circ} \mathrm{C}$, 30 cycles of $95{ }^{\circ} \mathrm{C}$ for $30 \mathrm{~s}$, annealing temperature $53{ }^{\circ} \mathrm{C}$ for $30 \mathrm{~s}, 72{ }^{\circ} \mathrm{C}$ for $30 \mathrm{~s}$ and a final extension period of $10 \mathrm{~min}$ at $72{ }^{\circ} \mathrm{C}$. The DNA amplifications were performed with fluorescent 5 ' dye-labeled primers and separated on an Applied Biosystems 3730xl automatic sequencer. The allele sizes were scored using GeneMapper ${ }^{\mathrm{TM}}$ v4.0 Software (Applied Biosystems).

Median allele sizes were computed as the median number of base pairs of all amplified fragments at a given locus for each of the three species 
Table I. Microsatellite loci amplification in three Bombus species. Number of genotypes sampled (n), amplification success, number of alleles present at each locus and median allele size in the museum sample for each of the three species studied. NA denotes a locus which failed to amplify for that species. Loci followed with the same superscript letter are amplified together in a multiplex reaction.

\begin{tabular}{lccccccccc}
\hline \multirow{2}{*}{ Locus } & \multicolumn{3}{c}{ B. appositus $(n=96)$} & \multicolumn{3}{c}{ B. occidentalis $(n=96)$} & \multicolumn{3}{c}{ B. huntii $(n=96)$} \\
\cline { 2 - 10 } & $\begin{array}{c}\text { Percent } \\
\text { amplified }\end{array}$ & $\begin{array}{c}\text { Number } \\
\text { alleles }\end{array}$ & $\begin{array}{c}\text { Allele } \\
\text { size }(\mathrm{bp})\end{array}$ & $\begin{array}{c}\text { Percent } \\
\text { amplified }\end{array}$ & $\begin{array}{c}\text { Number } \\
\text { alleles }\end{array}$ & $\begin{array}{c}\text { Allele } \\
\text { size }(\mathrm{bp})\end{array}$ & $\begin{array}{c}\text { Percent } \\
\text { amplified }\end{array}$ & $\begin{array}{c}\text { Number } \\
\text { alleles }\end{array}$ & $\begin{array}{c}\text { Allele } \\
\text { size (bp) }\end{array}$ \\
\hline BTERN01 $^{\mathrm{a}}$ & 97.92 & 14 & 88 & 88.54 & 15 & 110 & 86.46 & 19 & 112 \\
BL11 $^{\mathrm{b}}$ & 90.63 & 2 & 115 & NA & NA & NA & 93.75 & 5 & 116 \\
BT10 $^{\mathrm{a}}$ & 96.88 & 12 & 136 & 86.46 & 14 & 132 & 87.50 & 17 & 158 \\
BL13 $^{\mathrm{a}}$ & 76.04 & 5 & 165 & 52.08 & 3 & 181 & 64.58 & 6 & 171 \\
B10 $^{\mathrm{b}}$ & NA & NA & NA & 75.00 & 6 & 183 & 64.58 & 4 & 194 \\
BTERN02 $^{\text {b }}$ & 82.29 & 23 & 184 & 76.04 & 25 & 195 & 89.58 & 11 & 160 \\
BT28 $^{\mathrm{b}}$ & 87.50 & 8 & 198 & 81.25 & 7 & 186 & 91.67 & 5 & 186 \\
B124 $^{\mathrm{a}}$ & 72.92 & 8 & 249 & 56.25 & 7 & 243 & 66.67 & 6 & 227 \\
\hline
\end{tabular}

in the present study. The amplification success rate was computed at each locus by dividing the number of successful amplifications by the total number of genotypes for each species in each age class. Mean amplification success rates for each age class are the average of success rates across the three species (or two species for B10 and BL11). Amplification success rates were transformed with the arcsine $\sqrt{ } \mathrm{Y}$ function before analyses of proportional data. Statistical computations were carried out using SPSS v.15. Median allele sizes (in basepairs) across all loci within species were $165.5,175.7$ and 162.1 for B. huntii, B. occidentalis and B. appositus respectively.

Approximately $42 \%$ of the bees surveyed were male, primarily because we would have insufficient samples in age classes over 60 years old if only females were sampled. Whereas female bees are diploid, male bumble bees are haploid and the inclusion of males added some safeguards to this study. Microsatellite genotyping of historic, fragmented, low concentration template DNA is prone to errors such as allele dropout, the preferential amplification of one allele over another (Edwards et al., 2003). Because male bumble bees are haploid, they cannot be mistakenly mis-scored homozygous if one allele fails to amplify as could occur in a female. Additionally, haploid males serve as indicators of cross contamination at highly variable loci; a contaminated male specimen would likely appear as a heterozygote. Heterozygous, or diploid male bumble bees, are not common in nature and are a sign of severe inbreeding in Hymenopteran populations and males showing this condition could be retyped to determine if the observed diploidy was real or a result of contamination.

We evaluated differences in amplification success between male and female specimens by performing a one-way ANOVA comparing amplification success between males and females of the three species for five decadal groups in which more than five males and more than five females were available for all three taxa.

\section{RESULTS}

Male diploidy was not observed in the present experiment. There was no significant effect of gender on amplification success $(\mathrm{F}=$ 1.871 ; df $=1,219 ; P=0.173$ ) so males and female amplification success rates were combined for subsequent analyses.

Percents of successful amplification across all loci by age class were calculated and are given in Figure 1 for each species. A one way ANOVA was performed using all loci to test for the effect of species on amplification success rate. The rates of successful amplifications of $B$. appositus, B. huntii and B. occidentalis were $86.31,80.60$ and 73.66 , respectively. Amplification success from fresh material obtained from 188 individuals representing 27 Bombus species ranged from $90.5 \%$ (BT28) to 100\% (BL13) (including the species targeted in the present study) in a preliminary screening of the loci (Strange, unpublished data). There was no significant difference of 


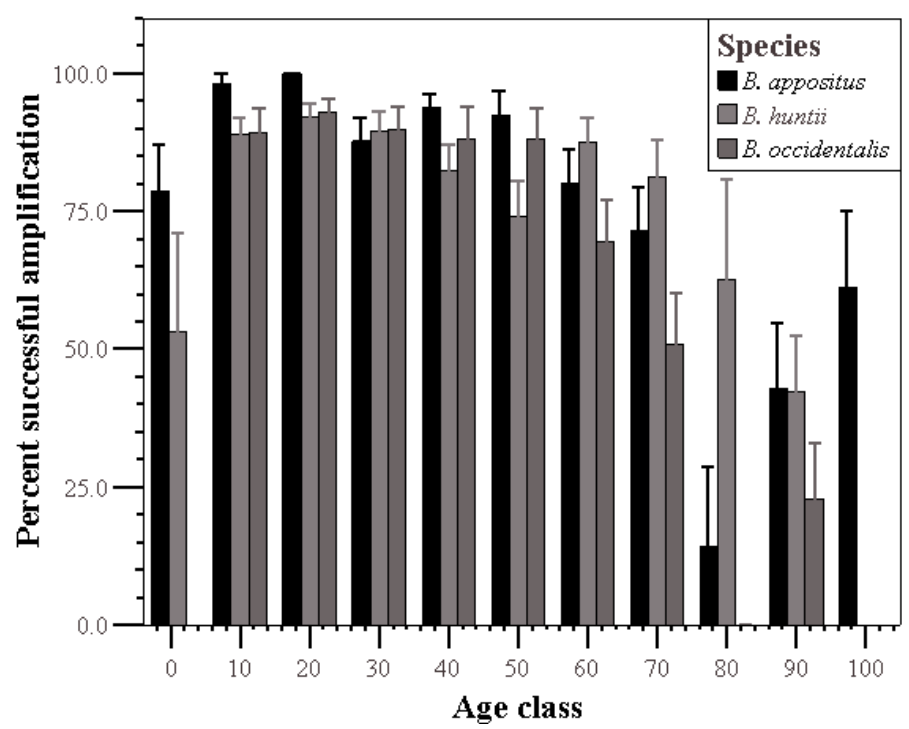

Figure 1. The percent amplification success averaged over eight microsatellite loci for various aged specimens of three species of bumble bees (Bombus). Different numbers of individuals were used in each decadal age class for each species depending on the number of individuals available for genotyping. Error bars represent standard error of the mean.

species on percent amplification success $(\mathrm{F}=$ $1.501 ; \mathrm{df}=2,219 ; P=0.225$ ).

Both median allele size and age of sample were significantly correlated to amplification success as smaller alleles and newer specimens tended to amplify more frequently than large alleles and older material. There was a significant negative relationship between the age of the sample and the amplification of alleles (Pearson correlation $\mathrm{R}=-0.485 ; P<$ $0.001 ; \mathrm{N}=219)$. Likewise a significant relationship (Pearson correlation $\mathrm{R}=-0.369$; $P<0.001 ; \mathrm{N}=219$ ) was found between the median allele size for a locus and the rate of amplification success at that locus.

\section{DISCUSSION}

The negative effects of time and allele size on DNA amplification success provide insight as to the utility of pin-mounted invertebrate collections for molecular studies. Although degradation of genetic material occurs, the rate of degradation (at least in large, heavily sclerotized bumble bees) progresses such that sufficient material can be obtained for analyses, even from specimens collected sixty years ago, when median allele size is within the range tested in the present experiment (Tab. I). Allele sizes amplified in the present study correspond to expected allele sizes routinely obtained from fresh specimens (Strange, unpublished data). Even in samples in the 100 year age class, $100 \%$ amplification success was achieved at two loci, BT10 and BTERN01 (median allele size 88bp and $136 \mathrm{bp}$, respectively), indicating that loci with shorter alleles may be utilized even in century old specimens. In fact, a third locus, BL11, with a median allele size of $115 \mathrm{bp}$ amplified in six of seven B. appositus collected in 1906 and 1907. Selection of appropriate loci will be important to further explore long term changes. When available, loci which yield shorter sequence alleles may prove to be more reliable than longer sequence alleles. Perhaps a greater danger of failure of a locus to amplify is the possibility that the longer of two alleles in a heterozygote could drop out over time, resulting in mis-scoring the individual as a homozygote. The bias toward short alleles must be considered when selecting loci for studies of diploid genomes in historic populations, 
to prevent under-representing allelic diversity, heterozygosity and $\mathrm{Ne}$.

Given the value of ancient material in invertebrate collections it is desirable to minimize damage to the specimen while collecting DNA sufficient for molecular analyses. Our results suggest that pinned bumble bee specimens in museum collections are suitable for population genetic studies and that extraction of DNA from single legs is an adequate method in most cases. It may be that other DNA isolation techniques could improve the yield of template DNA in material over 100 years old. However, the limited amount of archived material appears to be a greater obstacle than the molecular techniques used. For example, in the U.S. National Pollinating Insect Collection there are few adequately sized samples over sixty years old that could serve as source material for large scale population genetic studies.

DNA isolation techniques which yield larger quantities of template DNA may improve the reliability of microsatellite PCR from historical samples and may be necessary if the goal is to amplify longer sequences. These results show a similar decline in the percent of amplification success as previous studies (Watts et al., 2007) except that the decline in amplification success in bees seems to be slower than the previous work on damselflies. In our study, samples 50-59 years old amplified at all tested loci as often as in samples 10 years old whereas the oldest successful PCR in the damselfly study came from that age class. It may be that the sclerotization of the bumble bees helped preserve the material or the bulk of the material we were able to sample was larger. Amplification failures also occurred in younger material, indicating that other factors such as collection method or post collection handling may affect PCR results regardless of specimen age. Even though amplification success declines with specimen age, some collections may provide sample sizes large enough to provide adequate data for population level analysis.

This study demonstrates the utility of pinned insect specimens to generate multilocus genotypes sufficient to study changes in genetic diversity of populations over time. The technique presented here demonstrates the feasibility of using ancient DNA to generate multilocus genotypes usable to calculate population genetic parameters for $B$. occidentalis and other bumble bees whose populations may be in decline. Museum collections potentially provide material suitable to study genetic drift, mutation and gene flow over historical time frames at adequately sampled sites.

\section{ACKNOWLEDGEMENTS}

We thank James Pitts and Walter S. Sheppard and two anonymous reviewers for comments that greatly improved the manuscript. We owe a debt of gratitude to the many collectors who not only caught the specimens but who meticulously labeled and mounted the material insuring its usefulness.

Amplification d'ADN à partir d'exemplaires de bourdons (Bombus) préparés pour une collection entomologique de musée : influence de la taille du fragment et de l'âge du spécimen sur le résultat de la PCR.

Bombus / specimen de musée / génétique de la conservation / microsatellite / ADN ancien / PCR

Zusammenfassung - Amplifizierung der DNA von genadelten Hummeln (Bombus) einer Museumssammlung: Effekte der Fragmentgrösse und des Alters der Exemplare auf den Erfolg der PCR. Die Sammlungen entomologischer Museen enthalten grosse Zahlen an Exemplaren aus intensiv bearbeiteten Regionen und machen sie damit zu interessanten Quellen für longitudinale populationsgenetische Studien, die auch für den Artenschutz wichtig sein können (Groombridge et al., 2000; Rosenbaum et al., 2000; Goldstein and DeSalle 2003). Wir untersuchten die Möglichkeit, DNA aus den Beinen von genadelten Exemplaren von drei Hummelarten, Bombus appositus, Bombus huntii and Bombus occidentalis, für die Detektion von acht Mikrosatellitenloci zu nutzen, die eine grosse Variation in Allelgrössen aufweisen (Funk et al., 2006; Strange, unpubl. data). Dafür wurden 96 Exemplare jeder Art nach Sammelalter in 11 Gruppen eingeteilt, solche die vor 0-9 Jahren, 10-19 Jahren, 20-29 Jahren, ..., 100-109 Jahren gesammelt worden waren. Die DNA wurde aus Beinen mittels der Chelex ${ }^{\circledR}$ Extraktionsmethode gewonnen und wurde in zwei Multiplexreaktionen mittels PCR amplifiziert. Der Erfolg der PCR-Reaktionen lag für B. appositus bei $86,31 \%$, für $B$. huntii bei $80,60 \%$ und für $B$. occidentalis bei $73,66 \%$. Die mittlere Allelgrösse und das Alter der Exemplare war signifikant mit dem PCR-Erfolg korreliert, so dass kürzere 
Allele und jüngere Exemplare häufiger erfolgreich amplifiziert werden konnten als längere Allele und ältere Exemplare. Die negativen Effekt des Zeitfaktors (Abb. 1) und der Allelgrösse auf den PCRErfolg geben Aufschluss über die Verwendbarkeit von Invertebraten-Sammlungen für molekulare Untersuchungen. Obwohl es mit der Zeit zu einer Degradation des genetischen Materials kommt (zumindest im Fall von stark sklerotisierten Bienen), kann selbst aus sechzig Jahre alten Exemplaren immer noch genügend Material gewonnen werden, wenn die mittleren Allelgrössen innerhalb des von uns getesteten Rahmens liegen (Tab. I). Selbst hundert Jahre alte Exemplare wiesen einen hundertprozentigen Amplifikationserfolg an zwei Loci, BT10 und BTERN01 (mittlere Allelgrössen von 88bp, bzw. 136bp) auf. Dies zeigt, dass bei Loci mit kürzeren Allelen sogar hundert Jahre alte Exemplare verwendet werden können. Die Wahl zusätzlicher Loci sollte von Wichtigkeit sein, wenn eine Langzeitpopulationsdynamik gefragt ist.

\section{Bombus / Museumsexemplare / Artenschutz- genetik / Mikrosatellit / Alte DNA / PCR- Erfolgsrate}

\section{REFERENCES}

Austin J.J., Melville J. (2006) Incorporating historical museum specimens into molecular systematics and conservation genetics research, Mol. Ecol. Notes 6, 1089-1092.

Colla S.R., Packer L. (2008) Evidence for decline in eastern North American bumblebees (Hymenoptera: Apidae), with special focus on Bombus affinis Cresson, Biodivers. Conserv. 17, 1379-1391.

Darvill B., Knight M.E., Goulson D. (2004) Use of genetic markers to quantify bumblebee foraging range and nest density, Oikos 107, 471-478.

Edwards C.J., Connellan J., Wallace P.F. et al. (2003) Feasibility and utility of microsatellite markers in archaeological cattle remains from a Viking Age settlement in Dublin, Anim. Genet. 34, 410-416.

Ellis J.S., Knight M.E., Darvill B., Goulson D. (2006) Extremely low effective population sizes, genetic structuring and reduced genetic diversity in a threatened bumblebee species, Bombus sylvarum (Hymenoptera: Apidae), Mol. Ecol. 15, 43754386.

Estoup A., Solignac M., Cornuet J.-M., Goudet J., Scholls A. (1996) Genetic differentiation of continental and island populations of Bombus terrestris (Hymenoptera: Apidae) in Europe, Mol. Ecol. 5, 19-31.
Funk C.R., Schmid-Hempel R., Schmid-Hempel P. (2006) Microsatellite loci for Bombus spp., Mol. Ecol. Notes 6, 83-86.

Goldstein P.Z., DeSalle R. (2003) Calibrating phylogenetic species formation in a threatened insect using DNA from historical specimens, Mol. Ecol. 12, 1993-1998.

Groombridge J.J., Jones C.G., Bruford M.W., Nichols R.A. (2000) Conservation biology - "Ghost" alleles of the Mauritius kestrel, Nature 403, 616.

Harper G.L., McClean N., Goulson D. (2008) Analysis of museum specimens suggests extreme genetic drift in the adonis blue butterfly (Polyommatus bellargus), Biol. J. Linn. Soc. 88, 447-452.

Knight M.E., Martin A.P., Bishop S. et al. (2005) An interspecific comparison of foraging range and nest density of four bumblebee (Bombus) species, Mol. Ecol. 14, 1811-1820.

Konopinski M.K. (2008) A set of primers conserved in genus Parnassius (Lepidoptera, Papilionidae) for amplification and sequencing of $1016 \mathrm{bp}$ fragment of cytochrome oxidase subunit I from museum specimens, Mol. Ecol. Resour. 8, 675-677.

Martínková N., Searle J.B. (2006) Amplification success rate of DNA from museum skin collections: a case study of stoats from 18 museums, Mol. Ecol. Notes 6, 1014-1017.

McFrederick Q.S., Lebuhn G. (2006) Are urban parks refuges for bumble bees Bombus spp. (Hymenoptera: Apidae)? Biol. Conserv. 129, 372382.

Rosenbaum H.C., Egan M.G., Clapham P.J., Brownell R.L., Desalle R. (1997) An effective method for isolating DNA from historical specimens of baleen, Mol. Ecol. 6, 677-681.

Rosenbaum H.C., Egan M.G., Clapham P.J. et al. (2000) Utility of North Atlantic right whale museum specimens for assessing changes in genetic diversity, Conserv. Biol. 14, 1837-1842.

SPSS v.15 (2006) SPSS Inc. Chicago, IL.

Thorp R.W., Shepherd M.D. (2005) Profile: Subgenus Bombus, in: Shepherd, M.D., Vaughan D.M., Black S.H. (Eds.), Red List of Pollinator Insects of North America. CD-ROM Version 1 (May 2005). Portland, OR: The Xerces Society for Invertebrate Conservation.

Walsh P.S., Metzger D.A., Higuchi R. (1991) Chelex100 As A Medium for Simple Extraction of DNA for PCR-Based Typing from Forensic Material, Biotechniques 10, 506-513.

Watts P.C., Thompson D.J., Allen K.A., Kemp S.J. (2007) How useful is DNA estracted form the legs of archived insects for microsatellite-based population genetic analyses? J. Insect. Conserv. 11, 195-198. 